Scientia Agricola

http://dx.doi.org/10.1590/0103-9016-2014-0007

\title{
Genetic association between longevity and linear type traits of Holstein cows
}

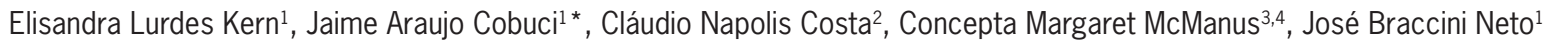

${ }^{1}$ Federal University of Rio Grande do Sul/Faculty of Agronomy - Dept. of Animal Science - Av. Bento Gonçalves, 7712 - 91540-000 - Porto Alegre, RS - Brazil.

2Embrapa Dairy Cattle, Eugênio do Nascimento, 610 - Dom Bosco - 36038-330 - Juiz de Fora, MG - Brazil.

3University of Brasilia, Campus Darcy Ribeiro s/n, Asa Norte - 70910-900 - Brasilia, DF - Brazil.

${ }^{4}$ National Institute of Science and Technology-Information-

Genetic Sanitary of Brazilian Livestock, Antonio Carlos, 6627

- 31270-901 - Belo Horizonte, MG - Brazil.

*Corresponding author <jaime.cobuci@ufrgs.br>

Edited by: Gerson Barreto Mourão

Received January 13, 2014

Accepted June 17, 2014

\begin{abstract}
Longevity is a desirable trait in the dairy industry because of its relationship to profitability. The aim of this study was to estimate genetic parameters for longevity measurements related to productive life, or life in the herd, and linear type traits of Brazilian Holstein cows born between the years 1990 and 2008. The (co) variance components were estimated by the restricted maximum likelihood method. The heritability for measurements of longevity and linear type traits ranged from 0.05 to 0.07 and 0.08 to 0.39 , respectively. The genetic correlations between measurements of longevity and linear type traits ranged from -0.39 to 0.31 . Direct selection for longevity does not necessarily lead to long-lived cows, due to low heritability. Indirect genetic selection for udder depth, bone quality, udder height, rear teat placement and conformation traits showed the highest genetic correlations with measurements of time between birth and last milk record and time from first calving to last milk record.

Keywords: genetic correlation, mammary system, productive life, rear teat placement
\end{abstract}

\section{Introduction}

Programs for the genetic improvement of dairy cattle generally aim at improving productive traits, with emphasis on milk production, which adversely affect other traits such as reproduction, health and longevity (Pérez Cabal et al., 2006). Longevity is a desirable trait in the dairy industry because of its relationship to profitability. The reduction of problems related to health and reproduction results in cows that remain in the herd for a longer time, increases the proportion of cows available for culling based on average milk production and reduces replacement costs (Sewalem et al., 2008).

Breeders in many countries have recognized the economic importance of longevity, have calculated genetic parameters of longevity and have included them in dairy cattle breeding programs (Forabosco et al., 2009). However, direct selection for longevity is limited by the time needed to obtain the records, usually after the death of the cow (Lagrotta et al., 2010) and low heritability, ranging from 0.03 to 0.13 (Vollema and Groen, 1997; Daliri et al., 2008).

Some researchers have evaluated the use of linear type traits as alternative indirect selection measurements of longevity due to favorable genetic correlations (Cruickshank et al., 2002; Zavadilová et al., 2009). Moreover, type traits are usually obtained early on during the productive life; are easy to measure and have higher heritability than longevity, commonly ranging from 0.08 to 0.49 (Daliri et al., 2008; Campos et al., 2012).

Genetic parameters are used to direct selection procedures, for prediction of genetic values and for the development of selection indices in genetic improvement programs. Considering the importance of longevity for dairy farming, the objective of this study was to esti- mate (co) variance components and genetic parameters for measuring longevity and linear type traits of Holstein cows, and to make recommendations for the inclusion of longevity in the Brazilian genetic evaluation system.

\section{Materials and Methods}

Data for this study consisted of type traits and longevity measurements taken from cows born between 1990 and 2008 and classified between 1995 and 2010 by technicians from the Brazilian Association of Holstein cattle Breeders (ABCBRH). These cows belonged to 375 herds distributed in the southeastern and southern regions of Brazil.

The linear classification system used by the AB$\mathrm{CBRH}$ includes 21 type traits based on direct measurements or visual scores of morphology expressed on a scale of one to nine points. These traits were divided into seven sections as in the Canadian model as follows: 1. Conformation (ST - stature; TL - top line; WE - weight; CW - chest width; BD - body depth; LS - loin strength), 2. Rump (RA - rump angle; RW - rump width), 3. Feet and Legs (FA - foot angle; BQ - bone quality; SV - side view of rear legs), 4. Anterior udder (FU - fore udder attachment; FT - fore teat placement; UTL - teat length), 5. Posterior udder (RH - rear udder height; RUW - rear udder width; RT - rear teat placement), 6. Mammary system (UD - udder depth; UT - udder texture; UC - udder cleft) and 7. Dairy form (AN - angularity), as well as Final Score (FS) where Dairy Form accounted for $12 \%$, Conformation (18\%), Feet and Legs (20\%) and Mammary System (8 \%), Rump (10 \%), Front Udder (14 \%) and Rear Udder (18\%).

Five longevity measures were evaluated: (i) total milk production over all lactations (Long1); (ii) number 
of lactations initiated (Long2); (iii) total number of days in lactation over all lactations (Long3); (iv) time between birth and last milk recording (Long4) in months; and (v) time from first calving to last milk recording (Long5) also in months.

To improve the database consistency for linear type traits, cows classified for type in the fourth or subsequent lactations and those cows with age at calving below 20 and above 87 months were excluded from the dataset. To reduce the influence of environmental factors on the analysis, ten lactation classes at classification (first to tenth month of lactation) and four classification periods were formulated: summer (January to March); fall (April to June); winter (July to September) and spring (October-December). Contemporary groups for type traits were formulated based on herd, year, and classification period, each one containing at least three cows. Additionally, each cow sire had at least two daughters in at least two herds.

As regards the consistency of longevity measurements, cows that might still be alive at the time of the analyses were excluded from the dataset. Two criteria were used to verify if the cows were still alive in the herd. The first was the presence of the last date of milk recording and the second consisted of the difference between the date of the cow's last calving (up to the time of data collection for each cow) and the date of the latest calving on each farm. If this difference was less than 24 months the cow was considered to be alive. The 24 month-period was used because about $95 \%$ of this population had a new calving during this period. This criterion was also used by Caetano et al. (2012) for Nelore cows.

Contemporary groups for longevity measuring were composed of herd, year and season of first calving, each one containing at least three cows. For the longevity analysis, the milk production in the first lactation and the age at first calving were divided into four classes. The classes of milk production in the first lactation were as follows: up to $6,500 \mathrm{~kg}, 6,501$ to $7,750 \mathrm{~kg}, 7,751$ to 9,000 and greater than $9,001 \mathrm{~kg}$ milk and the classes of age at first calving were up to 24 months, 25 to 26 months, 27 to 29 months and more than 29 months of age.

After the consistency of linear type traits and longevity measures, the number of records for the bivariate analysis including these traits, ranged from 19,318 (Long4) to 25,889 (Long1) (Table 1).

The bivariate models used for estimation of (co) variance for linear type traits and longevity included the fixed effects of contemporary groups, lactation class at classification, classifier (a technician from ABCBRH who carried out the morphological evaluation for type traits), classification period and age of the cow at classification date (covariate with linear and quadratic terms) for linear type traits and fixed effects of contemporary groups, classes of milk production in first lactation and classes of age at first calving for longevity measurements. Animal and residual random effects were common to all models.
Table 1 - Number of cows, bulls, cow dams, herds and contemporary groups in the Brazilian Holstein database, according to longevity measurements.

\begin{tabular}{lrrrrr}
\hline Database & Long1 & Long2 & Long3 & Long4 & Long5 \\
\hline Cows & 25,889 & 24,243 & 20,073 & 19,318 & 24,243 \\
Bulls & 1,092 & 1,058 & 965 & 950 & 1,058 \\
Cow dams & 21,026 & 19,696 & 16,535 & 15,945 & 19,696 \\
Herds & 375 & 334 & 321 & 308 & 334 \\
Contemporary groups & 2,129 & 2,030 & 1,799 & 1,735 & 2,030 \\
\hline
\end{tabular}

Long1 $=$ total milk production in all lactations; Long $2=$ number of lactations initiated; Long3= total number of days during all lactations; Long4= time between birth and last milk recording, in months; and Long $5=$ time from first calving to last milk recording, in months.

The bivariate model used in the estimation of (co) variance among linear type traits and longevity can be described as follows

$\left[\begin{array}{l}y_{1} \\ y_{2}\end{array}\right]=\left[\begin{array}{ll}X_{1} & 0 \\ 0 & X_{2}\end{array}\right] \times\left[\begin{array}{l}\beta_{1} \\ \beta_{2}\end{array}\right]+\left[\begin{array}{ll}Z_{1} & 0 \\ 0 & Z_{2}\end{array}\right] \times\left[\begin{array}{l}u_{1} \\ u_{2}\end{array}\right]+\left[\begin{array}{l}e_{1} \\ e_{2}\end{array}\right]$

where: $y_{i}$ is the vector of observations of the $i^{\text {th }}$ linear type traits $(i=1)$ and longevity measures $(i=2), \beta_{i}$ is the vector of fixed effects of the $i^{\text {th }}$ character, $u_{i}$ is the vector random effect of animal $i^{\text {th }}$ character, $e_{i}$ is the vector of residual effects of the $\mathrm{i}^{\text {th }}$ character, $\mathrm{X}_{\mathrm{i}}$ and $\mathrm{Z}_{\mathrm{i}}$ are incidence matrices relating to the observations of the $i^{\text {th }}$ character in the fixed and random effects of animal.

Estimates of (co)variance were performed by the restricted maximum likelihood derivative free method using MTDFREML software (Boldman et al., 1995). A convergence criterion of $10^{-9}$ was used, restarting the analysis at each convergence, using the final values of the previous analysis as initial values in the new analysis of (co)variance until no further difference existed in the four decimal values of -2 log likelihood between two successive analyses.

\section{Results and Discussion}

The mean scores for the 21 linear type traits ranged from 4.5 for teat placement to 7.2 for stature, showing no marked differences in relation to the ideal score recommended by $\mathrm{ABCBRH}$ (Table 2). The traits rump angle (5.0), udder depth (4.8) teat length (5.2) and top line (5.2) had a mean score closest to the ideal score and the traits fore udder attachment (6.0), rear udder width (6.0) and loin strength (6.3) presented mean scores more distant from the ideal score recommended (Table 2). The final score, which expresses the balance between the type traits of animals, was slightly above the minimum established as ideal, indicating the existence of a certain harmony between linear type traits in this population.

The proximity of the values of the traits to the ideal values is important for the continued genetic improvement of linear type traits in Brazilian herds, in order to obtain harmonic animals, a functional body structure 
Kern et al.

Longevity and type traits of Holstein cows

Table 2 - Mean, standard deviation (SD), ideal score, average estimate of additive genetic $\left(\sigma_{\mathrm{a}}^{2}\right)$ and residual $\left(\sigma_{\mathrm{e}}^{2}\right)$ variances and heritability for linear type traits in Brazilian Holstein cows obtained in bivariate analysis with all longevity measurements *

\begin{tabular}{|c|c|c|c|c|c|c|c|c|c|}
\hline \multirow{2}{*}{ Section/Trait } & \multirow{2}{*}{ Mean \pm SD } & \multirow{2}{*}{ Ideal Score } & \multicolumn{2}{|c|}{ Mean Variances } & \multicolumn{5}{|c|}{ Heritability ${ }^{1}$} \\
\hline & & & $\sigma_{a}^{2}$ & $\sigma_{\mathrm{e}}^{2}$ & Long1 & Long2 & Long3 & Long4 & Long5 \\
\hline \multicolumn{10}{|l|}{ Conformation } \\
\hline Stature & $7.2 \pm 1.31$ & 7 & 0.523 & 0.837 & 0.39 & 0.39 & 0.39 & 0.37 & 0.37 \\
\hline Top line & $5.2 \pm 1.06$ & $5-6-7$ & 0.139 & 0.673 & 0.17 & 0.18 & 0.18 & 0.16 & 0.17 \\
\hline Weight & $6.9 \pm 1.28$ & 9 & 0.275 & 0.804 & 0.26 & 0.26 & 0.26 & 0.25 & 0.25 \\
\hline Chest width & $5.8 \pm 1.24$ & 7 & 0.207 & 0.995 & 0.16 & 0.18 & 0.18 & 0.17 & 0.18 \\
\hline Body Depth & $6.2 \pm 1.08$ & 7 & 0.190 & 0.804 & 0.20 & 0.20 & 0.20 & 0.19 & 0.18 \\
\hline Loin strength & $6.3 \pm 1.35$ & 9 & 0.316 & 1.230 & 0.20 & 0.21 & 0.21 & 0.20 & 0.21 \\
\hline \multicolumn{10}{|l|}{ Rump } \\
\hline Angle & $5.0 \pm 1.02$ & $5-6-7$ & 0.290 & 0.693 & 0.31 & 0.30 & 0.30 & 0.28 & 0.28 \\
\hline Width & $6.5 \pm 1.23$ & 9 & 0.389 & 0.782 & 0.34 & 0.34 & 0.34 & 0.32 & 0.32 \\
\hline \multicolumn{10}{|l|}{ Feet and Legs } \\
\hline Foot Angle & $5.1 \pm 1.25$ & 7 & 0.098 & 1.074 & 0.09 & 0.09 & 0.09 & 0.08 & 0.08 \\
\hline Bone Quality & $6.6 \pm 1.37$ & 9 & 0.293 & 1.235 & 0.19 & 0.19 & 0.19 & 0.19 & 0.19 \\
\hline Side view of rear legs & $5.6 \pm 1.13$ & 5 & 0.185 & 1.026 & 0.16 & 0.16 & 0.16 & 0.15 & 0.14 \\
\hline \multicolumn{10}{|l|}{ Anterior Udder } \\
\hline Attachment & $6.0 \pm 1.51$ & 9 & 0.377 & 1.568 & 0.20 & 0.19 & 0.19 & 0.18 & 0.19 \\
\hline Teat placement & $4.5 \pm 1.18$ & 5 & 0.349 & 0.924 & 0.27 & 0.29 & 0.29 & 0.26 & 0.26 \\
\hline Teat length & $5.2 \pm 1.08$ & 5 & 0.350 & 0.768 & 0.31 & 0.32 & 0.32 & 0.31 & 0.30 \\
\hline \multicolumn{10}{|l|}{ Posterior Udder } \\
\hline Height & $6.4 \pm 1.34$ & 9 & 0.277 & 1.284 & 0.18 & 0.19 & 0.19 & 0.17 & 0.17 \\
\hline Width & $6.0 \pm 1.49$ & 9 & 0.230 & 1.323 & 0.15 & 0.14 & 0.14 & 0.16 & 0.16 \\
\hline Teat placement & $6.2 \pm 1.16$ & $5-6$ & 0.194 & 0.992 & 0.16 & 0.15 & 0.15 & 0.17 & 0.17 \\
\hline \multicolumn{10}{|l|}{ Mammary System } \\
\hline Depth & $4.8 \pm 1.18$ & $5-6$ & 0.270 & 0.845 & 0.26 & 0.24 & 0.24 & 0.23 & 0.24 \\
\hline Texture & $6.8 \pm 1.22$ & 9 & 0.088 & 0.951 & 0.08 & 0.09 & 0.09 & 0.08 & 0.08 \\
\hline Cleft & $6.4 \pm 1.54$ & 9 & 0.359 & 1.728 & 0.16 & 0.17 & 0.17 & 0.18 & 0.18 \\
\hline \multicolumn{10}{|l|}{ Dairy Form } \\
\hline Angularity & $6.4 \pm 1.18$ & 9 & 0.369 & 0.875 & 0.17 & 0.17 & 0.17 & 0.15 & 0.15 \\
\hline Final Score & $81.10 \pm 3.15$ & $>80$ & 0.885 & 4.714 & 0.15 & 0.16 & 0.16 & 0.16 & 0.17 \\
\hline
\end{tabular}

*Long1 = total milk production in all lactations; Long2= number of lactations initiated; Long3= total number of days during all lactations; Long4= time between birth and last milk recording, in months; and Long $5=$ time from first calving to last milk recording, in months. ${ }^{1}$ The standard deviations of heritability ranged from 0.00 to 0.022 for all type traits.

and good reproductive ability, enabling them to face the challenges of increasingly higher production levels, as these traits are genetically related to longevity (Darili et al., 2008; Makgahlela et al., 2009), leading to a higher permanence of cows in the herd with lower proportion of culling due to poor conformation, as well as health and reproduction problems.

Linear type classification is an important tool in the decision making process as it aims at the selection of animals which express their productive and reproductive potential through their phenotypic characteristics which should lead to longer herd productive life (PérezCabal and Alenda, 2002; Posadas et al., 2004).

Only the average estimate of these analyzes are reported because of the similarity between genetic and residual variances estimated in the multiple analyzes between each type traits and the five longevity measurements (Table 2 and Table 3). Likewise, averages of heritability for longevity measures were obtained in joint analyses with each type traits (Table 3 ).
The highest estimates of additive genetic (0.88) and residual (4.71) variance were observed for the final score (Table 2). These high estimates for final score are due to the original phenotypic scales which were higher for this trait than for other trait types. For the other type traits, estimates ranged from 0.08 to 0.52 and 0.67 to 1.72 for the additive genetic and residual variances, respectively. Except for foot angle and udder texture, the remaining linear type traits had estimates of additive genetic variance exceeding 0.13 , proportionally lower than the values of estimated residual variance.

Milk production in all lactations (Long1), as well as being a measurement of longevity (Table 3), measures the ability of the cow to delay involuntary culling. This measurement indicates that increased milk production per lactation reduces involuntary culling, allowing for culling to be based preferentially on production, which increases the breeding of cows with higher productive capacity and longer life in herds. 
Table 3 - Mean, standard deviation (SD), mean estimate of additive genetic variance $\left(\sigma_{a}^{2}\right)$ and residual $\left(\sigma_{e}^{2}\right)$ and mean heritability $\left(h^{2}\right)$ for longevity in Brazilian Holstein dairy cows obtained in bivariate analysis with all type traits*

\begin{tabular}{lcrrr}
\hline $\begin{array}{l}\text { Longevity } \\
\text { measures }\end{array}$ & Mean \pm SD & $\sigma_{\mathrm{a}}^{2}$ & $\sigma_{\mathrm{e}}^{2}$ & $h^{2}$ \\
\hline Long1 & $22,406.75 \pm 12,756.09$ & 451.89 & 9070.018 & 0.05 \\
\hline Long2 & $2.66 \pm 1.40$ & 0.07 & 1.04 & 0.07 \\
\hline Long3 & $970.88 \pm 491.91$ & 0.80 & 13.36 & 0.06 \\
\hline Long4 & $59.80 \pm 18.50$ & 13.49 & 200.37 & 0.06 \\
\hline Long5 & $33.35 \pm 18.15$ & 11.83 & 193.90 & 0.06 \\
\hline
\end{tabular}

Long1 = total milk production in all lactations; Long2= number of lactations initiated; Long $3=$ total number of days during all lactations; Long4= time between birth and last milk recording, in months; and Long5= time from first calving to last milk recording, in months. *Stature; Top line; Weight; Chest width; Body depth; Loin strength; Rump angle; Rump width; Foot angle; Bone quality; Side view of rear legs; Fore udder attachment; Teat placement; Teat length; Udder height; Udder width; Fore teat placement; Udder depth; Udder texture; Udder cleft; Angularity; Final score.

The average for Long2 (2.66) (Table 3) was similar to that observed in dairy cows in the United States of America by Tsuruta et al. (2005), with an average of 2.8 initiated lactations, slightly lower than those reported by Potočnik et al. (2011) in Slovenia and Strapák et al. (2011) in Slovakia, with averages of 3.0 and 3.4 lactations initiated, respectively, for Holsteins and Simmental dairy cows.

The cows remained, on average, 970 days in production (Long3) until their death or culling (Table 3). With the increase of total days in lactation, higher milk production and longer permanence of cows in the herd is expected, to be accompanied by a lower incidence of udder, reproductive and conformation problems (Cruickshank et al., 2002).

The mean values for the measurements of longevity of time between birth and last milk record (Long4) and time from first calving to last milk record (Long5) were approximately 60 and 33 months, respectively (Table 3). These values were similar to those reported by Nilforooshan and Edriss (2004), who obtained values of 57.2 months for Long 4 and 30.1 months for Long5.

In general, the low estimates of additive genetic variances associated with high residual variance estimates resulted in low heritability for all longevity measurements, ranging from 0.05 to 0.07 (Table 3). These estimates indicate that longevity is highly influenced by environmental factors and, therefore, indicate that direct selection based on these measurements leads to low genetic gains when selecting directly for longevity.

The heritability estimates for linear type traits had small variations when analyzed in bivariate analyses with different measures of longevity. The estimates were slightly higher when analyzed with Long1, Long2 and Long3, except for rear udder width, rear teat placement and udder cleft which showed higher heritability when analyzed jointly with Long4 and Long5 measures (Table 2).

The traits with highest heritabilities were stature (0.39 to 0.37$)$, rump width $(0.34$ to 0.32$)$ and teat length
(0.32 to 0.30$)$. Lower heritabilities were observed for foot angle (0.08 to 0.09) and udder texture (0.08 and 0.09). These results are similar to those reported by Zavadilová and Stípková (2012) in the bivariate analysis of Long5 with stature (0.41), rump width (0.35), teat length (0.27) and foot angle (0.10) and by Darili et al. (2008), for stature (0.38). Campos et al. (2012) also reported that foot angle (0.10) and udder texture $(0.11)$ were the characteristics that showed the lowest heritability in dairy cows in Brazil.

The estimated residual, phenotypic and genetic correlations ranged from -0.04 to $0.08,-0.05$ to 0.07 and -0.38 to 0.31 , respectively (Table 4). Estimates of genetic correlations between linear type traits with longevity measurements were higher than the corresponding phenotypic correlations. This result is similar to that reported by Cruickshank et al. (2002), with Jersey cows, who obtained higher estimates of genetic $(-0.29$ to 0.24$)$ than phenotypic $(-0.08$ to 0.10$)$ correlations between linear type traits and Long 4.

The values near nullity for residual and phenotypic correlations suggest that type traits and longevity are not influenced by the same factors or environmental effects and so it is practically impossible to predict the individual longevity of a cow in the herd through type phenotype. Estimates of phenotypic and genetic correlations reinforce the need to practice selection based primarily on values generated simultaneously by genetic evaluation procedures for such traits.

In general, genetic correlations between conformation traits with longevity measurements were negative and moderate, except for top line with Long 4 and Long5 $(-0.09)$ (Table 4). Genetic correlations indicate that cows with values for higher stature, top line, weight, chest width, body depth and loin strength have less opportunity to remain productive in the herd, due to negative genetic correlations of these traits with these longevity measurements.

As regards the traits related to the rump of the animal, genetic correlations between rump angle and all measures of longevity, and between rump width and Long1, Long 4 and Long 5 were low, ranging from - 0.10 to 005 , and suggest that selection for longevity through these two traits would lead to small genetic gains. In contrast, slightly higher genetic correlations between rump width with Long2 and Long3 were observed, indicating that a higher response to selection for longevity can be achieved by selecting daughters of bulls with narrower rump width. These results are similar to those observed by Zavadilová and Stípková (2012), who reported a genetic correlation between rump width and Long2 of -0.15 , and less than that observed by Cruickshank et al. (2002) and Zavadilová and Stípková (2012), who found correlations between rump width and Long 5 of -0.27 and Long 4 of -0.29 , in Jersey and Holstein cows, respectively. Rump traits are associated with calving ease, this being important for the dairy industry, where cows with calving problems are less profitable due to the increase in veterinary costs and 
Table 4 - Genetic, residual and phenotypic correlations between linear type traits and longevity in Brazilian Holstein cows, according to Conformation (1) Rump (2), Feet \& Legs (3), Anterior udder (4), Posterior udder (5), Mammary System (6) Dairy Form (7) and Final score (8).

\begin{tabular}{|c|c|c|c|c|c|c|c|c|c|c|c|c|c|c|c|c|c|c|c|c|c|c|}
\hline \multicolumn{23}{|c|}{ Sections } \\
\hline \multicolumn{7}{|c|}{1} & \multicolumn{2}{|c|}{2} & \multicolumn{3}{|c|}{3} & \multicolumn{3}{|c|}{4} & \multicolumn{3}{|c|}{5} & \multicolumn{3}{|c|}{6} & \multirow{2}{*}{$\begin{array}{c}7 \\
\text { AN }\end{array}$} & \multirow{2}{*}{$\begin{array}{c}8 \\
\text { FS }\end{array}$} \\
\hline & ST & $\mathrm{TL}$ & WE & $\mathrm{CW}$ & $\mathrm{BD}$ & LS & RA & RW & FA & $\mathrm{BQ}$ & SV & FU & FT & UTL & $\mathrm{RH}$ & RUW & RT & UD & UT & UC & & \\
\hline \multicolumn{23}{|c|}{ Genetic Correlation } \\
\hline NNG & -0.18 & -0.20 & -0.28 & -0.19 & -0.22 & -0.19 & 0.02 & -0.09 & 0.08 & 0.16 & -0.07 & 0.06 & 0.02 & 0.10 & 0.02 & -0.21 & -0.05 & 0.20 & 0.07 & 0.05 & -0.13 & -0.01 \\
\hline NG & -0.30 & $-0.21-$ & -0.33 & -0.23 & -0.26 & -0.19 & 0.06 & -0.17 & -0.01 & 0.14 & 0.02 & -0.04 & 0.02 & 0. & 09 & -0.27 & -0.01 & .17 & -0.07 & -0.05 & -0.29 & -0.07 \\
\hline DNG & -0.31 & -0.25 & -0.38 & -0.27 & -0.21 & -0.16 & 0.04 & -0.18 & -0.02 & 0.21 & 0.05 & 0.02 & 0.07 & 0.08 & 0.12 & -0.30 & 0.05 & 0.20 & 0.03 & -0.03 & -0.15 & -0.08 \\
\hline 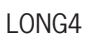 & -0.21 & -0.0 & -0.30 & -0.2 & -0.22 & -0.15 & 0.04 & -0.10 & -0.18 & 0.19 & -0.02 & 0.01 & 0.11 & 0.12 & 0.17 & -0.15 & 0.16 & 0.24 & 0.14 & 0.06 & -0.15 & 0.02 \\
\hline & -0.21 & -0.09 & -0.31 & -0.20 & -0.28 & -0.18 & 0.05 & -0.07 & -0.17 & 0.23 & -0.01 & 0.03 & 0.10 & 0.11 & 0.20 & -0.16 & 0.17 & 0.31 & 0.17 & 0.14 & -0.17 & 0.04 \\
\hline \multicolumn{23}{|c|}{ Residual Correlation } \\
\hline ONG1 & -0.01 & 0.00 & -0.01 & -0.01 & -0.02 & 0.01 & 0.01 & -0.01 & 0.00 & 0.03 & 0.00 & 0.01 & -0.01 & 0.00 & 0.02 & 0.02 & 0.00 & -0.01 & 0.01 & 0.02 & 0.03 & 0.08 \\
\hline ONG2 & 0.02 & $0.01-$ & -0.01 & 0.00 & - 0.02 & 0.01 & 0.02 & -0.01 & -0.01 & 0.02 & 0.00 & 0.01 & -0.02 & - 0.01 & 0.00 & 0.02 & -0.02 & 0.00 & 0.01 & 0.03 & 0.03 & 0.08 \\
\hline LONG3 & 0.02 & 0.00 & 0.00 & 0.00 & -0.01 & 0.01 & 0.01 & 0.00 & 0.00 & 0.02 & 0.00 & 0.02 & -0.02 & -0.02 & 0.01 & 0.02 & -0.02 & 0.02 & 0.00 & 0.03 & 0.02 & 0.08 \\
\hline LONG4 & 0.02 & 0.00 & -0.01 & 0.00 & - 0.02 & 0.00 & 0.00 & -0.01 & 0.01 & 0.00 & 0.01 & 0.02 & -0.04 & - 0.02 & 0.00 & 0.00 & -0.04 & 0.04 & 0.00 & 0.02 & 0.01 & 0.06 \\
\hline LONG5 & 0.02 & 0.00 & 0.00 & 0.00 & -0.02 & 0.01 & 0.00 & -0.01 & 0.01 & 0.00 & 0.00 & 0.02 & -0.03 & -0.02 & 0.00 & 0.00 & -0.03 & 0.04 & 0.00 & 0.01 & 0.01 & 0.06 \\
\hline \multicolumn{23}{|c|}{ Phenotypic Correlation } \\
\hline בNC1 & -0.03 & -0.02 & -0.04 & -0.0 & -0.04 & -0.01 & 0.01 & -0.02 & 0.00 & 0.04 & 0.00 & 0.01 & -0.01 & 0.01 & 0.02 & 0.00 & 0.00 & 0.01 & 0.01 & 0.02 & 0.01 & 0.07 \\
\hline LONG2 & -0.03 & -0.01 & -0.05 & -0.03 & -0.05 & -0.01 & 0.02 & -0.03 & -0.01 & 0.03 & 0.00 & 0.00 & -0.01 & 0.01 & 0.01 & -0.01 & -0.02 & 0.02 & 0.00 & 0.02 & 0.00 & 0.06 \\
\hline LONG3 & -0.03 & -0.02 & -0.05 & -0.03 & -0.03 & -0.01 & 0.01 & -0.03 & 0.00 & 0.04 & 0.00 & 0.02 & -0.01 & 0.00 & 0.02 & -0.01 & -0.02 & 0.04 & 0.00 & 0.02 & 0.00 & 0.06 \\
\hline & -0.02 & -0.0 & -0.04 & -0.0 & -0.04 & -0.01 & 0.00 & -0.02 & 0.00 & 0.02 & 0.00 & 0.02 & -0.01 & 0.00 & 0.02 & -0.01 & -0.02 & 0.06 & 0.01 & 0.02 & 0.00 & 0.05 \\
\hline LONG5 & -0.02 & -0.01 & -0.04 & -0.02 & -0.05 & -0.01 & 0.00 & -0.02 & 0.00 & 0.02 & 0.00 & 0.02 & -0.01 & 0.00 & 0.02 & -0.01 & -0.01 & 0.07 & 0.01 & 0.02 & 0.00 & 0.06 \\
\hline
\end{tabular}

$\mathrm{ST}=$ Stature; $\mathrm{TL}=\mathrm{Top}$ line; $\mathrm{WE}=$ Weight; $\mathrm{CW}=$ Chest width; $\mathrm{BC}=$ Body depth; $\mathrm{LS}=\mathrm{Loin}$ strength; $\mathrm{RA}=\mathrm{Rump}$ angle; $\mathrm{RW}=\mathrm{Rump}$ width; $\mathrm{FA}=\mathrm{Foot}$ angle; $\mathrm{BQ}=\mathrm{Bone}$ quality; SV= Side view of rear legs; FU= Fore udder attachment; FT= Teat placement; UTL= Teat length; RH= Udder height; RUW= Udder width; RT= Fore teat placement; UD= Udder depth; UT= Udder texture; UC= Udder cleft; $A N=$ Angularity; FS= Final score; Long1= Total milk production in all lactations; Long2= Number of lactations initiated; Long3= Total number of days during all lactations; Long4= Time between birth and last milk recording, in months; and Long5= Time from first calving to last milk recording, in months.

deaths in calves, thereby increasing involuntary culling, and substantially affecting longevity in the herd (Sewalem et al., 2008).

The genetic correlations between traits of the feet and legs section and measures of longevity, ranged from -0.18 to 0.23 (Table 4). Estimates for the side view of rear legs and all measures of longevity, and between foot angle with Long1, Long2 and Long3 were close to zero, indicating that they are not good predictors of longevity. In contrast, the estimates for foot angle with Long 4 and Long 5 were negative and moderate, indicating that the problems associated with the foot angle tend to decrease the persistence of the cows in the herd. The highest genetic correlations, although moderate, were between longevity and traits of feet and legs and between bone quality and Long $5(0.23)$. Thus, cows with high scores for bone quality may remain longer in the herd.

Although the traits of the feet and legs section presented moderate to low genetic correlations, Schneider et al. (2003) observed that cows with a low degree of bone surface, presenting a clean, flat angle, an extremely low foot angle and legs that were extremely curved or straight showed a considerable decrease in Long5. This decrease can be explained by the increase in involuntary culling due to illnesses related to feet and legs. Onyiro et al. (2008) found moderate genetic correlation with bone quality $(-0.21)$ and high corre- lation between the side view of rear legs $(-0.63)$ and digital dermatitis, reporting that cows without disease had good quality, flat bones and good set of the legs and feet, this being associated with increased herd longevity.

The low genetic correlations between the fore udder and longevity traits suggest that selection based on fore udder attachment, fore teat placement and fore teat length, has little influence on longevity. Zavadilová and Stípková (2012) and Zavadillová et al. (2009) also had low correlations with Long 5 and fore udder attachment 10.04 and -0.08).

The moderate and positive values for the genetic correlations between rear udder height (0.17 and 0.20) and rear teat placement $(0.16$ and 0.17$)$ with Long4 and Long 5 indicate that selection based on these traits may favor the permanence of cows in the herd. The same cannot be said between rear udder height and rear teat placement with Long1 (0.02 and -0.05), Long2 (0.09 and -0.01) and Long3 (0.12 and 0.05) that showed low genetic correlations, suggesting that few genes involved in the expression of rear udder height and rear teat placement also influence longevity (Long1, Long2 and Long3).

The genetic correlations between rear udder width and measures of longevity $(-0.30$ to -0.15$)$ suggest that cows with wide rear udder, have lower longevity. This result clearly illustrates the decreased longevity of cows 
assigned to intensive selection for milk production in recent years, because cows with large udders have high genetic correlation with milk production (0.46 to 0.65$)$ (Cruickshank et al., 2002; Esteves et al., 2004), and cows with high milk production are more likely to suffer involuntary culling, due to the higher incidence of udder health problems, such as mastitis (Rupp and Boichard, 1999; Carlén et al., 2004).

Udder depth in the mammary system section showed the highest positive genetic correlations with longevity measurements, ranging from 0.17 to 0.31 , with emphasis on Long4 (0.24) and Long5 (0. 31). Higher genetic correlations between traits leads to the possibility of selection based on just one trait, when two are genetically correlated. The choice of which to use depends on factors such as heritability, cost, ease of collection and time for taking measurements of the traits. Selection for udder depth, preferentially obtained in first lactation, has higher heritability (0.23 to 0.26 ) than longevity measures (0.05 to 0.07$)$, has a lower cost as it is collected early in life and presents moderate correlations with longevity (0.17 to 0.31), and, therefore, can be used as an auxiliary measure for indirect selection for longevity.

The genetic correlations between measurements of longevity and other traits of the mammary system section were low, except for udder texture and Long5 (0.14) and Long4 (0.17), and the mammary system cleft and Long5 (0.14), indicating that indirect selection for longevity based on these traits would affect Long4 and Long5. The moderate to low negative genetic correlations between angularity and longevity measurements show that cows with good angularity have lower longevity. This type trait also represents the structure of a cow and showed genetic correlation similar to traits in the conformation section.

The estimates of genetic correlations between final score and longevity measurements were close to zero $(-0.08$ to 0.04$)$. These values are similar to those reported by Samoré et al. (2010) and Zavadilová and Stípková (2012), among final score and Long5 and Long2, respectively. The low genetic correlation between longevity measurements and final score, according to Zavadilová and Stípková (2012), could result from the improper choice of traits and their weights to form the final score. However, Caraviello et al. (2003) and Sewalem et al. (2004) observed a strong linear relationship between final score and longevity in Holstein and Jersey cows, respectively, reducing the risk of culling animals with a high final score. The final score deserves special attention because it expresses the balance of the cow for all type traits (Esteves et al., 2004).

In general, the genetic correlations between linear type traits and longevity measurements were moderate to low, indicating that indirect selection for longevity based on linear type traits may not translate into significant correlated gains in longevity. When the indirect gain in longevity was calculated to consider the type trait that had the highest genetic correlation (weight,
-0.38), this gain was approximately $20 \%$ lower than that found with direct gain, i.e. without taking into account the generation interval. If the generation interval were to be included in the calculation of the gain, however, this could result in a greater gain in longevity, due to the longer period needed to obtain longevity compared to type measurements. Indirect selection for longevity based on type traits is, therefore, less efficient than direct selection, but can be justified since type traits are already collected by the breed associations, and are easily measured and obtained at the beginning of the productive life, usually at the first lactation.

The highest positive genetic correlations were between traits related to udder, feet and legs with Long4 and Long5, indicating that selection based on these traits may result in higher genetic longevity gains. Traits in the conformation section also showed high, but negative genetic correlations with Long4 and Long5 measurements.

\section{Conclusion}

Direct selection for longevity implies small and long-term genetic gains for the cows due to the low estimates of heritability found for productive life. Linear type traits associated with the mammary system such as udder depth, udder height and rear teat placement as well as bone quality, and traits of the conformation section had higher heritability than the longevity measurements. They represented considerable genetic correlations with measurements of time between birth and last milk record, and time from first calving to last milk record and may, therefore be used for indirect selection for longevity.

\section{Acknowledgement}

The authors thank the Brazilian Association of Holstein Cattle Breeders (ABCBRH) for supplying the data, which were essential for the development of this study, and also the Coordination of Improvement of Higher Education Personnel (CAPES) for granting the scholarship.

\section{References}

Boldman, K.G.; Kriese, L.A.; Van Vleck, L.D.; Van Tassell, C.P.; Kachman S.D. 1995. A manual for use of MTDFREML: a set of programs to obtain estimates of variances and covariances. Available at: ftp://aipl.arsusda.gov/pub/outgoing/mtdfreml/ mtdfrman.pdf [Accessed May 15, 2013].

Caetano, S.L.; Rosa, G.J.M.; Savegnago, R.P.; Ramos, S.B.; Bezerra, L.A.F.; Lôbo, R.B.; De Paz, C.C.P.; Munari, D.P. 2012. Characterization of the variable cow's age at last calving as a measurement of longevity by using the Kaplan-Meier estimator and the Cox model. Animal 7: 540-546.

Campos, R.V.; Cobuci, J.A.; Costa, C.N.; Neto, J.B. 2012. Genetic parameters for type traits in Holstein cows in Brazil. Revista Brasileira de Zootecnia 41: 2150-2161. 
Caraviello, D.Z.; Weigel, K.A.; Gianola, D. 2003. Analysis of the relationship between type traits, inbreeding, and functional survival in Jersey cattle using a Weibull Proportional Hazards Model. Journal of Dairy Science 86: 2984-2989.

Carlén, E.; Strandberg, E.; Roth, A. 2004. Genetic parameters for clinical mastitis, somatic cell score, and production in the first three lactations of Swedish Holstein cows. Journal of Dairy Science 87: 3062-3070.

Cruickshank, J.; Weigel, K.A.; Dentine, M.R.; Kirkpatrick, B.W. 2002. Indirect prediction of herd life in Guernsey Dairy Cattle. Journal of Dairy Science 85: 1307-1313.

Daliri, Z.; Hafezian, S.H.; Shad Parvar, A.; Rahimi, G. 2008. Genetic relationships among longevity, milk production and linear type traits in Iranian Holstein Cattle. Journal of Animal and Veterinary Advances 7: 512-515.

Esteves, A.M.; Bergmann, J.A.G.; Durães, M.C.; Costa, C.N.; Silva, H.M. 2004. Genetic and phenotypic correlations between type traits and milk production in Holstein cattle. Arquivo Brasileiro de Medicina Veterinária e Zootecnia 56: 529-535 (in Portuguese, with abstract in English).

Forabosco, F.; Jakobsen, J.H.; Fikse, W.F. 2009. International genetic evaluation for direct longevity in dairy bulls. Journal of Dairy Science 92: 2338-2347.

Lagrotta, M.R.; Euclydes, R.F.; Verneque, R.S.; Santana Júnior, M.L.; Pereira, R.J.; Torres, R.A. 2010. Relationship between morphological traits and milk production in Gir cows. Pesquisa Agropecuária Brasileira 45: 423-429 (in Portuguese, with abstract in English).

Makgahlela, M.L; Mostert, B.E.; Banga, C.B. 2009. Genetic relationships between calving interval and linear type traits in South African Holstein and Jersey cattle. South African Journal of Animal Science 39: 90-92.

Nilforooshan, M.A.; Edriss, M.A. 2004. Effect of age at first calving on some productive and longevity traits in Iranian Holsteins of the Isfahan Province. Journal of Dairy Science 87: 2130-2135.

Onyiro, M.O.; Andrews, J.L.; Brotherstone, S. 2008. Genetic parameters for digital dermatitis and correlations with locomotion, production, fertility traits, and longevity in Holstein-Friesian dairy cows. Journal of Dairy Science 91: 4037-4046.

Pérez-Cabal, M.A.; Alenda, R. 2002. Genetic relationships between lifetime profit and type traits in Spanish Holstein cows. Journal of Dairy Science 85: 3480-3491.

Pérez-Cabal, M.A.; García, C.; Gonzàlez-Recio, O.; Alenda, R. 2006. Genetic and phenotypic relationships among locomotion type traits, profit, production, longevity, and fertility in Spanish dairy cows. Journal of Dairy Science 89: 1776-1783.
Posadas, M.V.; López, F.J.R.; Valdenegro, H.H.M. 2004. Estimation of genetic parameters for longevity traits and milk production in Holstein cattle in Mexico. Interciencia 29: $52-56$ (in Spanish, with abstract in English).

Potočnik, K.; Gantner, V.; Krsnik, J.; Štepec, M.; Logar, B.; Gorjanc, G. 2011. Analysis of longevity in Slovenian Holstein cattle. Acta Agriculturae Slovenica 98: 93-100.

Rupp, R.; Boichard, D. 1999. Genetic Parameters for clinical mastitis, somatic cell score, production, udder type traits, and milking ease in first lactation Holsteins. Journal of Dairy Science 82: 2198-2204.

Samoré, A.B.; Rizzi, R.; Rossoni, A.; Bagnato, A. 2010. Genetic parameters for functional longevity, type traits, somatic cell scores, milk flow and production in the Italian Brown Swiss. Italian Journal of Animal Science 9: 145-152.

Schneider, M.; Durr, J.W.; Cue, R.I.; Monardes, H.G. 2003. Impact of type traits on functional herd life of Quebec Holsteins assessed by survival analysis. Journal of Dairy Science 86: 4083-4089.

Sewalem, A.; Kistemaker, G.J.; Miglior, F.; Doormaal, B.J. van. 2004. Analysis of the relationship between type traits and functional survival in Canadian Holsteins using a Weibull Proportional Hazards Model. Journal of Dairy Science 87: 3938-3946.

Sewalem, A.; Miglior, F.; Kistemaker, G.J.; Sullivan, P.; Doormaal, B.J. van. 2008. Relationship between reproduction traits and functional longevity in Canadian Dairy Cattle. Journal of Dairy Science 91: 1660-1668.

Strapák, P.; Juhás, P.; Strapáková, E. 2011. The relationship between the length of productive life and the body conformation traits in cows. Journal of Central European Agriculture 12: 239-254.

Tsuruta, S.; Misztal, I.; Lawlor, T.J. 2005. Changing definition of productive life in US Holsteins: effect on genetic correlations. Journal of Dairy Science 88: 1156-1165.

Vollema, A.R.; Groen, F.A. 1997. Genetic correlations between longevity and conformation traits in an upgrading dairy cattle population. Journal of Dairy Science, 80: 3006-3014.

Zavadilová, L.; Němcová, E.; Štípková, M.; Bouška, J. 2009. Relationships between longevity and conformation traits in Czech Fleckvieh cows. Czech Journal of Animal Science 54: 387-394.

Zavadilová, L.; Štípková, M. 2012. Genetic correlations between longevity and conformation traits in the Czech Holstein population. Czech Journal of Animal Science 57: 125-136. 